\title{
Chapter 3 \\ Becoming Undocumented: Legislation and Asylum Processes in Finland
}

\subsection{Introduction}

The phenomenon of irregular migration is very complex in Finland, as in many other European countries (Ambrosini 2018; Düvell 2006, 2011; Thomsen and Jørgensen 2012). Definitions and practices regarding migrants, asylum seekers, and undocumented migrants are blurred, and clear-cut categories do not account for what the real lives of these people involve (Crawley and Skleparis 2018). The term 'undocumented migrant' (and the other terms that are used to more or less correctly identify this 'category') identifies a process of becoming undocumented-which leads to changing rules, regulations, and exceptions - rather than a static, easily definable phenomenon. Migrants often move between different 'immigration categories' during their migration processes (Goldring and Landolt 2013). It is possible to change status from undocumented to documented, and from an irregular migrant with almost no rights and responsibilities to a migrant with a residence permit and extensive rights, in a given country. Being an undocumented migrant is always simultaneously about becoming an undocumented migrant.

Five issues can be highlighted here. Firstly, stricter asylum and residence policies cannot completely prevent the arrival of migrants in the EU; thus, the number of undocumented migrants is likely to keep increasing (International Organisation for Migration 2018; Czaika and Hobolt 2016). Secondly, despite international law giving countries the right to make decisions about the presence of non-citizens in their territories, no country has as yet been able eliminate undocumented migrants (Triandafyllidou and Vogel 2010); therefore, they live among legally resident inhabitants, building liminal spaces of semi-legality and semi-regularity and, in some cases, even performing 'experiments of citizenship'. Hellgren claimed a social membership for undocumented migrants, 'which refers to actual participation in society, for example integration into the local neighbourhood and labour market, regardless of legal status' (2014: 1177). Thirdly, when the possibilities of earning a legal income are constrained, undocumented migrants turn to semi-legal or illegal 
means of earning money; the informal grey economy then expands, and local and national tax revenues are consequently lost (Lewis et al. 2015; Orrenius and Zavodny 2016). Fourthly, when social and health services are not readily available, undocumented migrants utilise unauthorised medical services or do not use them at all. Untreated illnesses can lead to unpredictable events, especially if people with serious, untreated psychological traumas are left to deal with them alone (Andersson et al. 2018; Bustamante et al. 2018). Finally, the exclusion of undocumented migrants leads to increasing harmful segregation in the EU member states and to a spreading influence of rumours-particularly in social media (Dekker and Engbersen 2014; Leurs and Ponzanesi 2018)—on their actions and decisions.

Legal definitions are the key focus in this chapter, because becoming and being undocumented depends mostly on the law. States usually apply binary logics of regular/irregular or legal/illegal when they try to frame migrants in their territories; however, in the everyday lives of undocumented migrants, there are no such clearcut, dichotomous distinctions. Instead, they live in-between categories (Sarausad 2019). Furthermore, undocumented migrants have very different legal positions in different countries, even within the EU (see Triandafyllidou 2016). In some countries their stay is tolerated, they are allowed to work, and they have access to many public services; in others, they are denied the right to work and barely have access to healthcare. Such liminal legality has characteristics of both documented and undocumented statuses (Ambrosini 2018: 5-6), whereby the border between the two cannot always be clearly identified. Finland is among the countries in which undocumented migrants have few rights (see Sect. 3.2).

In Sect. 3.2, we discuss the key legislation and legal perspectives pertaining to undocumented migrants in Finland. Since Finland is a member of the EU, much of this discussion is relevant in an EU context for indicating how undocumented migrants are produced by legal systems. As we discussed in the introduction to this book, the majority of undocumented migrants (in Europe and beyond) live in an in-between condition of liminality, whereby they can neither arrive nor stay-and, in a few cases, cannot even leave (Tsoni 2016): 'Liminal legality is neither an undocumented status nor a documented one but may instead have the characteristics of both' (Ambrosini 2018: 5-6). The definition of undocumented migrant remains blurred, in both the international literature and migration policies (unless it is said that he/she is an outright illegal immigrant; that is, a person who does not have the right to reside in the country). In Finland, a person either has or does not have the right to reside. In this section, we will discern who belongs in which category and the situations in and between categories. In Sect. 3.3, we explain the complex asylum process in Finland and how failing this process is the path to becoming an undocumented migrant (Gill 2016), if a person does not leave the country. We look at the process from both sides: from the viewpoint of the authorities who decide whether to grant asylum, and that of undocumented migrants who request asylum. As we show, the same person can move back and forth between the statuses of documented and undocumented migrant. In some cases, the authorities have to tolerate the presence of undocumented migrants in Finland (for the situation of 'tolerated' irregular migrants in Germany, see Jauhiainen et al. 2019), because they cannot legally return 
them to their countries of origin. In Sect. 3.4, we provide a short overview of the status of undocumented migrants and asylum seekers, locally and nationally, in Finland during the 2010s. Finally, in Sect. 3.5, we present the conclusions of the chapter.

\subsection{Defining Undocumented Migrants in Finland: The Legal Perspective}

Various terms are used to describe people whose presence in a country is somehow legally dubious (Anderson and Ruhs 2010); that is, whether they have met all the required legal criteria to enter and reside in a given country. Determining the legal status of a migrant is far from easy, as noted over 10 years ago by one of the topic's leading scholars, Franck Düvell (2008: 489): 'The extent to which a clandestine immigrant needs to conceal him or herself varies from country to country and depends on each one's legislation and enforcement practices'.

We will now consider the specific case of Finland, taking into consideration that every county has its own rules defining the different types of migrants whose stays are considered to be irregular/illegal. Such a detailed approach is useful for comparing the case of Finland with other countries. In the case of Finland, since the law does not explicitly define who is an undocumented migrant, the issue has to be looked at from the reverse viewpoint; namely, who has the right to reside in Finland. Finland's Ministry of the Interior (2018b) asserted: 'Finnish legislation stipulates that everyone should have a clear status in society and no one should reside in the country illegally'. The right to reside in the country can be permanent or temporary, and many kinds of people have permanent or fixed-term rights to stay in Finland, as discussed below.

Citizens of Finland have the permanent right to reside in Finland and this permanent right in Finland to enter, stay and leave is reserved for citizens. Residence in Finland means that one is legally allowed to stay in Finland and has legally valid residence in one of Finnish municipalities, which is not the case for undocumented migrants.

A person can become a Finnish citizen by birth (i.e. one's mother is a Finnish citizen; one's father is a Finnish citizen married to a foreign national, or the Finnish father's paternity has been established; or in specific cases, one may also be born the child of a Finnish female couple, or born in Finland without any other citizenship). In cases of births outside Finland involving unmarried Finnish fathers or children of Finnish female couples, Finnish citizenship is gained by declaration. Other cases of Finnish citizenship by declaration are, for example, former Finnish citizens; people 18-22 years old who have lived in Finland for 6 to 10 years (with specific conditions, including not having been sentenced to imprisonment); adopted children between 12 and 17 years of age; or citizens of Nordic countries who have been permanent residents in Finland for at least 5 years. A person can also gain Finnish citizenship by 
naturalisation through an administrative process. This requires an application and the fulfilment of several criteria (including being 18 years of age, a resident permanently domiciled in Finland for the past 5 years, not having committed any major punishable act, not having any public debt, able to provide a reliable account of livelihood, and satisfactory oral and written skills in the Finnish or Swedish language; Migri 2019g). People can simultaneously hold other citizenships than that of Finland.

People other than Finnish citizens can also enter Finland legally and obtain legal residence in the country. A person can be a citizen of a country for which no visa is required to travel to Finland; people with this status can remain in Finland for the duration of the visa-free residence period, which is usually up to 90 days. Another case is to have a Schengen residence permit granted by another country that allows the person to reside in Finland, usually for a short period of time. Yet another case is to come from a country whose citizens need a visa to enter Finland and have such a valid visa for a determined period of time (Migri 2019g).

If a person stays in Finland for more than 90 days and arrives in Finland from outside the EU, Iceland, Liechtenstein, Norway, or Switzerland, he/she must apply for a residence permit. If specific conditions are fulfilled, the residence permit is issued. The first permit is always for a fixed term, but can become a continuous residence permit, and finally a permanent residence permit after staying for several years in Finland and fulfilling specific criteria. If a person is a citizen of an EU member state, Iceland, Liechtenstein, Norway, or Switzerland, that person does not need a residence permit for Finland, but must register his/her residence in Finland; therefore, without a residence permit, or through failing to register the residence, a person enters a state of irregularity after remaining in Finland for more than 3 months. With a fixed or continuous residence permit, a person can enter a state of irregularity by continuing to stay in Finland after the validity of such a residence permit has expired. The reason may be that the permit was not renewed, because the person no longer met the criteria or that the person did not apply for it. There are people in Finland who remain in the country for several years after their residence permission has expired. These people need to live in a particular way, having no contact with the authorities, or to possess fake personal identification documents. When a person has obtained a permanent resident permit, he/she cannot become an undocumented migrant in Finland as long as the permit is valid; that is, until further notice from the authorities.

There are thus many ways to become a legal resident of Finland and, also, many ways to become a person who does not have the right to reside in Finland. For example, the stay in Finland of a citizen of an EU member state can become irregular. In principle, EU citizens are exempt from entry and immigration regulations, but they need to demonstrate economic self-sufficiency, follow public security regulations, and register their residency if staying for more than 90 days. As Könönen (2020) pointed out, however, the inability to support oneself economically or the likelihood of becoming an unreasonable burden on the state can result in a removal order (Maslowski 2015), as can failure to comply with public policy, public security, or public health requirements (Queiroz 2018: 49-50), leading to cancellation of the residence permit. In principle, the mobility of EU member-state citizens is 
free within the Schengen area, so they do not have to register their entrance to Finland and the police cannot randomly check their documents or their right to stay in Finland. Police can check the identity of a person and his/her right to remain in Finland only in specific cases mentioned in the Aliens Act. It is thus rather easy for an EU member-state citizen to remain in Finland, even if his/her right to remain has expired. This applies to many kinds of people, such as former students, employed EU nationals, tourists, or any types of visitors. This also explains why there are a considerable number of Bulgarian and Romanian citizens, especially ones with ethnic Roma backgrounds, as well as some Estonians without proper work permits, among the migrants who are in some way irregular in Finland. If detained for a criminal offence, they can be returned to their home countries, from where they can return to Finland rather easily within the Schengen area despite the ban on entry (see Könönen 2020). This creates circular irregular migration between their country of citizenship and Finland.

People of most nationalities need a visa to enter Finland, potentially constituting the largest category of people who become undocumented migrants. In principle, three kinds of people enter Finland. Firstly, there are people who enter Finland legally with visas. The authorities issue an individual visa for a limited time (from days to weeks, and sometimes for months) and for a specific purpose (tourism, work purposes, or visiting family members); however, some remain in Finland after the visa has expired and/or lost its validity. A portion of these people have forgotten to renew their visas or residence permits, while others have simply not bothered to do so.

Secondly, there are people who enter Finland legally by requesting asylum. As discussed, they form the largest group of undocumented migrants. Most asylum seekers fail in their attempts to obtain asylum and/or residence permits in Finland. Some become undocumented migrants during the asylum process (e.g. by failing to attend an asylum interview or appeal within a specific time, in which case they should leave the country and await the court's decision outside Finland; see Sect. 3.3). The majority, however, become undocumented migrants after receiving final negative decisions on their applications. If they do not leave the country within 30 days of the first negative decision from Migri and do not appeal against such a decision, they become undocumented migrants (see Sects. 2.4, 3.3, and 4.2). Likewise, if they interrupt the asylum process and do not leave Finland, they become undocumented migrants.

Thirdly, there are people who enter Finland illegally without visas (if such are required) or during a period when their entry into Finland is banned. A growing number and diversity of people travel within the Schengen area from one country to another without the proper right to do so. Some fail the asylum process in one EU member state and move to another EU member state (in this case, Finland). Knowing that another asylum application would probably be rejected, they do not bother to reapply, but instead live as undocumented migrants in the country. Some people (usually former asylum seekers or refugees) have obtained permanent residence in a specific EU member state, but for some reason do not want to live there. Instead, they move to another EU member state, such as Finland, perhaps because they have better 
social networks in Finland, prefer the living standards there, or experience pushing factors in their country of residence. If they do not meet the criteria for permanent residence in Finland, they are likely to hide and remain anonymous to the authorities. There are also people who never start the asylum process, but travel without permission to Finland and remain there as undocumented migrants. Their reasons are often similar to those of many failed asylum seekers, and they often have additional economic motivations (see Chap. 4). The number of such people is increasing in Finland. In principle, people without the right to remain in Finland should be removed from the country; however, the police are often forbidden to randomly ask and verify whether a certain person has the right to remain in Finland. Even when they find people whose right to remain in Finland has ceased (such as former asylum seekers) or who did not have it in the first place, the police do not necessarily take any action. According to Koivula (2020), the police in Helsinki (and in other areas) may not even fine these people, knowing from experience that it will have no consequences (i.e. the people will not pay the fines and the fines will not make them leave Finland). Such people might be informed that they must leave Finland and that there are assisted voluntary mechanisms to help them do so, but the police can do little more.

\subsection{The Asylum Process}

The asylum process in Finland, as elsewhere in the EU, from requesting asylum (international protection) to the national authorities' final decision (i.e. whether the person will be protected), is a complex process. Internationally agreed-upon principles exist regarding the human rights and definitions of a refugee. The well-known definition of 'refugee' in the 1951 Convention Relating to the Status of Refugees and the 1967 Protocol emphasises fear of persecution due to race, religion, nationality, membership of a particular social group, or political opinion (United Nations 1951).

In addition, many EU policies regarding asylum processes have been harmonised (see for instance the Asylum Procedures Directive), but they became difficult to be universally and uniformly implemented in the EU after 2015 (Niemann and Zaun 2018): 'The implementation of the Asylum Procedures Directive is thus not only a top-down process, but is also shaped by domestic asylum policies and the officials' local working environments' (Schittenhelm 2019: 231). Indeed, 'because of their diversity, and because they are subject to different arenas of political bargaining, migration policies are bound to display internal incoherencies "by design", depending on the specific migrant categories and policy areas at stake' (De Haas et al. 2016: 3); therefore, national differences exist between asylum processes and the consequences of failing such processes (i.e. whether a person then becomes an undocumented migrant and with what rights (if any) in the EU member states. In this section, we present the main legal asylum procedures in Finland. For details of the asylum process, see Migri 2019b). 
Upon presentation of an asylum application in Finland, the validity of the asylum applicant's claims is inspected in due course and, as a result, the application is either approved, granting the person international protection, or rejected, denying the person such protection (Migration and Home Affairs 2019). Usually, after applying, the person (who has thus become an asylum seeker) is directed to a reception centre to await the decision.

If the asylum application is approved, the person receives international protection, thus becoming a refugee with many rights, including that of permanent residence in Finland. The person can also obtain a residence permit on other grounds, such as subsidiary protection, family, or work. A final rejection means that the person is not protected and has no right to reside in Finland on the grounds of international protection. If this person does not receive a residence permit on other grounds (as explained below), he/she must leave Finland within 30 days of the decision, otherwise his/her presence in Finland is illegal and he/she becomes an undocumented migrant. The person can be then detained and forcibly removed from the country; however, the movements and everyday lives of such migrants, although to some extent involving a rigid legal/illegal dichotomy, often end up challenging the clear-cut validity of such a dichotomy (Schweitzer 2017) through the actual reality that these people live (Black 2003; Crawley and Skleparis 2018; Gonzales 2016; Menjívar 2006).

\subsubsection{The Asylum Process from the Viewpoint of the Authorities}

To apply for asylum in Finland, a person must be within Finnish territory. Finland has long land borders with Sweden and Norway and, in many places, people can enter Finland without encountering any border formalities, border control authorities, or police. In principle, a person who wishes to apply for asylum needs to declare their intention immediately, at the border, to a border control official or the police, or to the police at the nearest police station, otherwise he/she does not have the right to enter the country and entering Finland is illegal. Not all asylum-related migrants request asylum immediately, but may do so later, within a few days of their entry. In such cases, they have entered and remained in Finland illegally and have already become undocumented migrants (i.e. people with no legal right to reside in Finland). In fact, according to the national authorities (such as the police), people who (for convenience, or through distraction or procrastination) do not immediately request asylum, but do so later, are counted as undocumented migrants who have exposed themselves voluntarily to the authorities. In the legal and administrative sense, people with a legitimate reason to enter Finland, who request asylum immediately, are not undocumented migrants, but those who enter illegally and apply for asylum later are undocumented migrants, with no right to enter and reside in Finland. 
This administrative difference regarding asylum applications, which follows rigid legal/dual categorisations and taxonomies (legal/illegal), poses a challenge for ascertaining the exact number of undocumented migrants in Finland. The police register how many times they encounter people who are living in Finland illegally. This happened around 2000 to 3000 times annually, with the exception of 2015, when it became common (2933 in 2014, 14,286 in 2015, and 2314 in 2016; see Jokinen 2017). The large increase in 2015 was due to arrival of a high number of asylum seekers, of whom many (perhaps as much as a third) applied for asylum at the 'wrong' time and place (i.e. not immediately at the border, but later).

Immediately after a person requests asylum from the police or a border control official, these authorities register the individual's personal data and record biometric identifiers (photograph and fingerprints) and signature (Migri 2019b). Thereafter, the asylum seeker is moved to a transit centre for a short period while the authorities determine whether the asylum process is Finland's responsibility (Migri 2018a: 5). The person's fingerprints are entered into the EU asylum fingerprint database, Eurodac. This database was created in 2003 to support the implementation of the so-called Dublin Regulation (Regulation No. 604/20133) and assist in determining an EU member state's responsibility for examining an asylum application made in the EU.

If Finland has the responsibility for processing the asylum application, the applicant is sent to a reception centre (Ministry of the Interior 2011). The national migration service, Migri, is responsible for handling the asylum application (with application meaning a process, since no official form has to be filed). The asylum seeker is also informed about his/her rights and responsibilities during the asylum process (Migri 2018a: 5). In particular cases, when the authorities cannot identify the asylum seeker, or his/her travel route is unclear at the time of application, the potentially irregular entry can lead to the detention of the applicant until such information is made available to the authorities (Könönen 2020).

Following the large number of asylum seekers in 2015, over 200 temporary reception centres were established across Finland. An asylum seeker cannot select a reception centre: the authorities decide where he/she is sent. For very vulnerable asylum seekers, specific centres and services are available. Having a reception centre in a municipality generates employment and various services there, so many centres are located in remote places (Jauhiainen 2017). Running such centres also became a profitable enterprise for some private or NGO stakeholders because, in 2015-2016, the national authorities had to rapidly establish contracts with service providers. After 2017, the number of reception centres gradually decreased.

An asylum seeker does not have to pay for food or accommodation in a reception centre. The asylum seeker can also opt for private accommodation outside the reception centre if he/she organises it personally and pays the accommodation costs. All asylum seekers, including those who do not live in reception centres, have the right to access the services of such centres. They also have the right to work after 3 months in Finland with a valid travel document that entitles them to cross the border, or 6 months in Finland without one (Migri 2019h). 
After the initial registration and reception centre designation, Migri first evaluates the grounds for asylum via a desk procedure. During the desk procedure, Migri considers whether an application needs to be processed or dismissed. The immediate cases of dismissal can be, for instance: Migri considers the asylum seeker's country of origin safe; the asylum seeker is a 'Dublin case' (i.e. he/she has been registered as an asylum seeker in another EU member state, Norway, Switzerland, or Liechtenstein, where his/her asylum application should be processed); or it is a subsequent asylum application that does not present any new grounds for seeking asylum (Migri $2019 \mathrm{k}$ ). If the application is dismissed, and if certain circumstances apply, the asylum seeker must leave Finland and can be removed from the country within 8 days by the police or the border guards responsible for enforcing the refusal of entry.

In so-called 'Dublin cases', Migri issues the refusal of entry order to the asylum seeker, but it cannot issue a direct removal order. In fact, the transfer of the asylum seeker to the appropriate EU member state requires an agreement between the authorities of Finland and the respective member state. In all such cases, the removal from Finland is not allowed. Könönen (2020) indicated that, in Finland, most detention orders for asylum applicants were issued for forced removal and, in particular, related to the enforcement of the Dublin Regulation (in 2016, mainly for Iraqi, Somali, and Afghan citizens). In addition, several North African nationals have applied for asylum multiple times in EU member states before arriving in Finland. Such 'Dublin mobility' is sometimes related to social or family ties and reapplications provide temporary access to welfare services; however, many of these people have been detained in Finland. The detention of asylum applicants can be ordered if they disappear from the reception centres (although, with notice, the applicants have the right to live outside the centres) or if they try to leave Finland during the asylum process or go underground to avoid the police after notification of the negative decision (Könönen 2020). Following the increase of the number of undocumented migrants in Finland, their removal became more difficult, and detention as a mechanism to precipitate their removal became less effective (Koivula 2020).

If the asylum application is not rejected in the desk procedure phase, the asylum seeker waits for an invitation to attend an asylum interview with a Migri official. This usually takes several months, and sometimes more than a year, between the asylum request and the interview. The asylum interview invitation states the language into which the interview will be translated, as well as the exact location and time of the interview, which cannot be changed. A new regulation that came into force in the summer of 2018 states that Migri needs to make asylum application decisions, in principle, within 6 months; however, there are exceptions to this rule (Migri 2018a: 7).

Meanwhile, each asylum seeker receives a monthly allowance, the amount of which (usually around 315 EUR) depends on what kind of assistance (shelter, or food and shelter) is provided to the asylum seeker. It is also expected (although not compulsory) that asylum seekers will participate in activities provided by the reception centre, such as language courses. The law indicates, however, that 
integration-supporting services should start only when an asylum seeker receives a positive answer (Finnish Red Cross 2019); therefore, during the asylum process, the asylum seekers are in legal limbo (a liminal space; O'Reilly 2018)—inside Finland, but not entirely in Finland. The national government formed in 2019 plans to determine whether integration services should be made available during the asylum process (Government of Finland 2019). In reception centres, the asylum seekers are provided with general information about the asylum process and the option to have a legal counsel; however, it is not the duty of the reception centre to provide or organise asylum seekers' legal aid. The organisation of legal aid is, in principle, the duty of Migri. Migri has claimed that many new reception centres opened in 2015-2016 were not able to provide asylum seekers with adequate information about the asylum process (Migri 2018a: 7). If an asylum seeker commits a crime, the crime investigation is kept separate from the processing of the asylum application; however, the asylum application process will be accelerated. If he/she is convicted of a crime, he/she may serve a sentence in Finland.

In an asylum interview, Migri asks the identity of the interviewee, his/her travel route to Finland, and all the reasons why he/she is applying for asylum in Finland. The information received in the asylum interview (including possible supporting documents) determines Migri's decision on the person's application for asylum (Migri 2019k). The asylum seeker has the right to the presence of a legal counsel at the asylum interview. The interviewer decides at the beginning of the interview whether any other support person may participate, and counsel decides whether it is necessary for him/her to participate. If, however, the asylum seeker wants to be accompanied by the legal counsel during the interview, without good reason, he/she may be required to pay the expenses him-/herself. The legal counsel is paid to attend the interview only if there are justified reasons (i.e. the asylum seeker is in clear distress, is in apparent need of help, or is an unaccompanied minor). During an asylum interview with a Migri official, an asylum seeker does not automatically have any legal representation unless he/she is less than 18 years old and unaccompanied; however, basic legal support is provided throughout this first phase of the asylum process, from the asylum seeker's application to the Migri decision phase (Migri 2019c). Finland has been criticised for not providing sufficient legal aid for asylum seekers during the initial asylum process (Lepola 2018). Following the formation of the new Government of Finland in 2019, the possibility of improving legal assistance for asylum seekers during the asylum process is being inspected (Government of Finland 2019).

To support asylum interviews, interpreters are hired by Migri and the conversations are recorded and transcribed. The interview can be accessed thereafter, for instance, to determine possible mistakes or misunderstandings in the translation. In many cases, the simultaneous translation has been organised at a distance and the quality of transmission has been poor (Migri 2018a: 14); as Puumala et al. (2018) highlighted: 'At the end of each interview, the interpreter back-translates the transcript to the claimant who can make additions or corrections to it. By signing the transcript, the claimant accepts that it is an accurate documentation of their narration'. One drawback, repeatedly highlighted by our research participants (former 
asylum seekers) was that the asylum interview was such a stressful experience that the interviewees were afraid to report the mistakes they found in the transcripts; for example, some of them said that they were afraid of failing the interview if they reported mistakes, since this might have displeased the officials (these could be cases of epistemic violence; see Gadd and Lehtikunnas 2019). This process is, in general, rather similar in many EU member states. It may be difficult to determine in hindsight whether any major mistakes were made in the translation, especially if the interviewee approved its validity and accuracy by signing it; however, Migri made random quality checks on written translations of asylum interviews and discovered inconsistencies in the quality or accuracy of the translations, even to the extent that they could affect the final asylum decisions (Migri 2018a: 21-22).

After inspecting an applicant's asylum request, including the interview, Migri makes the decision on his/her asylum request. The grounds to grant asylum vary, but in principle follow the reasons mentioned in the Convention relating to the Status of Refugees (United Nations 1951). Migri (2019j) states:

You may get asylum in Finland if you have a well-founded fear of being persecuted in your home country or your country of permanent residence because of your origin, religion, nationality, membership in a certain social group, or political opinions. Another requirement is that you cannot rely on the protection of the authorities of your home country or country of permanent residence because of the persecution you fear.

If Migri issues a negative decision on an asylum application, the asylum seeker has the right to appeal to the Administrative Court within 21 days of the decision (Migri 2019a, d). All those who do not appeal, but who remain in the country beyond 30 days from the date of decision, are then considered to be people who do not have the legal right to stay in Finland-thus, in the national administrative texts, they are referred to as illegal immigrants (in Finnish, laiton maahanmuuttaja or laittomasti maassa oleva). More precisely, they are not, in fact, illegal people, but people whose immigration is illegal.

There have been claims that Migri's decisions do not always strictly follow the legal procedures or that, due to lack of legal counsel in the process, asylum seekers cannot express themselves appropriately, which may lead to rejection of their applications (Gadd and Lehtikunnas 2019; Lepola 2018; Migri 2018a). The problems in the Finnish asylum process have been criticised by many NGOs, including Amnesty International. In fact, Administrative Court decisions regarding appeals by asylum seekers against Migri's decisions have overturned many of Migri's decisions, suggesting that Migri should change them. In 2015, $19 \%$ of the Administrative Court decisions on asylum seekers' appeals led to Migri's initial decisions being changed or the cases being returned to Migri for review and probable change. By 2017, this number had risen to 36\% (Lepola 2018: 8). The approval rate (asylum, subsidiary protection, or residence due to humanitarian reasons) following court decisions in Finland was the highest in the EU in 2018 (i.e. 68\% in Finland and 38\% in the EU; Eurostat 2019). This is not mentioned as a criticism of Migri, but to highlight that many asylum decisions for first-level applications were not entirely 
convincing. Asylum policies and decisions are part of broader political processes in Finland, as in every country (Gibney 2004).

In fact, in 2019, the European Court of Human Rights (ECHR) gave its judgment concerning Finland in the case of the return of an asylum seeker to Iraq. The person had sought international protection in Finland against returning him to Iraq in 2015; however, Migri rejected his application for asylum. The Administrative Court dismissed the appeal, and the Supreme Administrative Court did not grant leave for the asylum seeker to appeal. Later, it was said that the applicant was killed in Iraq. The ECHR held that Article 2 (right to life) and Article 3 (prohibition of torture and inhuman treatment) of the European Convention on Human Rights had been violated when processing his asylum application in Finland (Ministry for Foreign Affairs 2019). This was the first time that Finland ever received such a decision from the ECHR. Such a decision meant that the actual removal to Iraq, with a ban on entry for Iraqis who had failed their asylum processes, was temporarily suspended at the end of 2019; however, in 2020, the Finnish police suspected that the asylum seeker's family staged his death after his return to Iraq to obtain financial compensation from Finland (Yle.fi 2020).

Migri includes an assisted voluntary return and reintegration programme within the framework of the Reception Act. An asylum seeker who applies for voluntary return (during the asylum process, including within 30 days of receiving a negative decision on his/her application) is an exception: he/she will not be removed from Finland even if his/her allowed period of stay has expired (Migri 2018d), but can stay in Finland until return arrangements have been completed. Voluntary return is proposed as a viable option for asylum seekers upon their arrival in Finland and during their stays in reception centres: 'Assistance with voluntary return may cover the costs of the return trip and financial assistance, in order to enable the returning immigrant to start a new life in the home country' (Ministry of the Interior, Finland 2019). The return is assisted by the International Organisation for Migration (IOM) and the Finnish authorities. The IOM assists voluntary returnees with pre-departure counselling, travel arrangements, and post-arrival reintegration assistance, among other services.

The payments for voluntary asylum seeker returnees increased in 2019, according to their countries of origin. In 2017, the amount of cash payments increased up to 1500 EUR, and in 2019, payments for goods up to 5000 EUR (Yle.fi 2019a). The final amount is paid to the returnee when he/she arrives in the country of origin. Despite the Finnish authorities' frequent support for voluntary return, it has not so far become popular: 'In 2017, the number of people who returned voluntarily amounted to 1,422 . The number was significantly lower than the previous year [2016] when 2,113 people returned voluntarily' (Ministry of the Interior, Finland 2018a: 89). In 2018 , the number of voluntary returnees fell to 646 people. In 2016-2018, roughly 3.8 million EUR was granted to 4181 voluntary returnees; on average, the amount was 1437 EUR per person in 2018. In addition, the travel costs for these people were reimbursed, amounting to 1.5 million EUR between September 2016 and August 2018 (i.e. more than 500 EUR per person). From Migri's perspective, assisting return is economically the most efficient solution. Only 40 days in a reception centre 
costs the same as the average money spent on voluntary return assistance (including the return travel) and the maximum support for voluntary return would equal 100 days in such a centre. Some asylum seekers spend from months to years in reception centres. About three out of four voluntary returnees come from Iraq (Yle.fi 2019b).

An asylum seeker who stays in Finland and, after appealing to the Administrative Court, receives a decision from the Administrative Court that does not change Migri's initial rejection decision (the so-called second negative decision), can appeal again to the Supreme Administrative Court (Migri 2019f), unless his/her decision does not grant leave to appeal. He/she has 14 days to appeal after receiving the decision from the Administrative Court; however:

If you have appealed the decision [from Migri], you are allowed to wait for the Administrative Court's decision in Finland. If you apply to the Supreme Administrative Court for leave to appeal, this will not prevent the enforcement of the negative decision unless the Supreme Administrative Court expressly orders that it may not be enforced. (Migri 2019d)

A person can therefore, potentially, apply to the Supreme Administrative Court and be removed from Finland unless this court orders differently. In general, refusal of entry decisions (i.e. decisions to remove a person from Finland before he/she has received a residence permit) may be issued in the following cases: (a) after the first negative decision from Migri, if an appeal to the Administrative Court is not presented within 21 days, and the person does not leave Finland or does not apply for voluntary return within 30 days; (b) if the individual can be sent to another country that is responsible for examining the asylum application according to the Dublin Regulation (Migri 2019e); or (c) immediately after the second negative decision from the Administrative Court, if a 'stop deportation' is not promptly issued.

Indeed, when a second appeal is presented to the Supreme Administrative Court and the court does not order differently, the court's decision must be awaited outside Finland; thus, the individual can be removed from Finland at any time. For this, Migri makes the refusal of entry decision (and the decision becomes automatically final when the deadlines for presenting appeals or leaving the country expire). The decision is then enforced by the police unless a request to stop enforcement is submitted to the Administrative Court within 7 days. Once a final refusal of entry decision is given (if the Supreme Administrative Court does not change Migri's and the Administrative Court's decisions; i.e. the so-called third negative decision), the person is considered to be in Finland illegally if no period for voluntary departure has been granted or the obligation to return has not been complied with. Following the EU return directive (article 11:1), for EU citizens and for third-country nationals with legal residence in another EU member state, the entry ban is issued nationally, and for others it covers the whole Schengen area.

To avoid their removal from the country, some asylum seekers start a subsequent asylum application after the first one fails, either directly following Migri's first negative decision or the courts' second or third negative decision. As explained previously, if the subsequent application does not contain new grounds for asylum, it 
is rejected immediately at the desk procedure stage; therefore, subsequent applications require substantial and significant novel grounds. According to Migri (2018b), 'the new grounds that are given are most often that the applicant has converted to Christianity while in Finland or that the applicant belongs to a sexual or gender minority'. Some asylum seekers attempt to make their stay legal by claiming to have changed their religion (Migri 2017), sexual preference, or gender, or asserting that they did not express it clearly enough during the first application procedure. Especially in Islamic countries, but not only there, changing religion from Islam to Christianity or being gay can lead to serious consequences, including death. Such a person (in this case, an asylum seeker in Finland) would be persecuted upon returning to his/her country of origin, which would create an obstacle for Finnish authorities removing him/her from Finland; therefore, some asylum seekers who do not leave Finland opt for this solution. Some have been awarded asylum on these grounds, but others, who have not been able to demonstrate the truthfulness of their claims, have not been granted asylum, as Migri (2017) stated:

If an applicant tells us that they are seeking asylum due to having converted to Christianity and being persecuted in their home country, they are asked for more details. We do not automatically grant asylum or a residence permit to applicants who have been baptised [in Finland], for example.

Overall, to survive, undocumented migrants may adopt a variety of 'masks', or multiple identities, in response to the demands of a hostile receiving environment (Mac an Ghaill et al. 2000; Schweitzer 2017). These masks are materialisations of their need to survive: they are actual strategies that allow them to cope with their stressful and precarious living conditions. If undocumented migrants change religion (for instance, if they become Christian, as some do in Finland), whether their claim is genuine or not, many need to put on a mask and hide this from their peers or family (who might not accept the change of religion). On the other hand, if they need to be accepted in the Christian community, they might need to partially or totally hide or deny the culture from which they come.

Some asylum seekers have made fake statements about their change in religion or sexual preference just for the purpose of trying to stay in Finland; however, cases also exist in which these changes have been genuine. Discerning the truthfulness of the intent is very difficult; however, this is what Migri is asked to evaluate in each case (see also Fassin 2013) and the Administrative Court and the Supreme Administrative Court have found some (but few) Migri decisions on these issues to be incorrect (Migri 2018a: 50-54).

An asylum seeker who has claimed to be Christian or gay (but has not been convincing enough to obtain asylum in Finland), and is actually removed to a country in which the conversion of religion or sexuality is a serious legal or social offence, may face very serious or even fatal consequences, and his/her family might also. Few studies have yet been published about the destiny of those undocumented migrants (or asylum seekers) who have been removed from Finland; however, reports have appeared in the media claiming that some of them have died in conflicts, for example, in Iraq or Afghanistan (Yle.fi 2018). Overall, results for the asylum 
process showed that, from 2015-2017, only a minority of asylum seekers received asylum or residence permits in Finland.

Furthermore, geopolitical complexities in the 2010s, in areas from which the majority of asylum seekers come, have also increased difficulties for authorities in justifying their negative decisions; for example, the situations have often worsened in the areas which the asylum seekers left and this (the so-called 'sur place' principle, on account of events which took place after the asylum seeker left his/her country of origin), and other cumulative reasons, must be taken into account in asylum decisions. In principle, such decisions should favour the asylum seekers (for the benefit principle in cases of doubt, see Migri 2018a: 61-65).

\subsubsection{The Asylum Process from the Viewpoint of Undocumented Migrants}

Viewpoints on the asylum process differ substantially between authorities and asylum seekers; therefore, in the following section, we briefly discuss the viewpoints of undocumented migrants who failed the asylum process (those to whom asylum or a residence permits were not granted in Finland).

In our survey of undocumented migrants, five out of six $(85 \%)$ had initiated the asylum process in Finland (i.e. they had asked for asylum). One out of nine (11\%) came to Finland without seeking asylum. They did not request it mainly because they suspected that it would be a useless process that would restrict them for a long time and, ultimately, would probably lead to rejection and becoming an undocumented migrant. Some of them visited extended family and friends in Finland, and others had found sufficiently good jobs in Finland to earn enough money to survive. Obviously, such employment was not regular, because the people were in Finland without legal permission. The remaining few (4\%) entered and resided in Finland for other reasons.

Becoming and being an undocumented migrant is a processual, non-linear social phenomenon, consisting of various events and changes, as McAuliffe and Koser (2017: 344) noted: 'Irregularity is not a fixed experience-regular migrants may become irregular, irregular migrants may be regularised'. What role does the asylum process play in this path towards, and experience of, becoming undocumented? One of the most relevant elements seems to be the general lack of knowledge and/or understanding of the asylum process itself, which is one of the elements that can lead to becoming undocumented. As presented in the previous section (in a simplified manner), the procedure seems logical and straightforward-despite the many technicalities and bureaucratic steps-with clear deadlines and consequences; however, this is not what most asylum seekers perceive, especially those who become undocumented migrants. They do not consider the bureaucratic procedures (Könönen 2018): they are too busy finding new survival strategies and/or new ways of concealing their 'irregular status' (Tedeschi 2021b). The lack of clarity 
and the misunderstandings during the asylum process, resulting in asylum seekers' inability to handle it and/or flawed final decisions, are widespread in Europe and have been broadly covered by the international academic literature (Gill 2016; Kälin 1986; Schuster 2018).

First of all, the majority of undocumented migrants are not fully aware of what 'asylum' means. This was one clear finding from our ethnographic fieldwork. Their main purpose was, and is, to be safe and legalise their stay in Finland. To do that, they might apply for asylum, since this is the first possibility presented to them upon arrival in Finland if they come from countries considered to be (possibly) unsafe. Later, especially when their asylum applications are rejected, if they do not completely abandon the idea of legalising their stay, they may try to obtain a residence permit by other means; for example, through work, study, or family ties (e.g. getting married during the asylum process, often to a Finn, and having children with him/her) in Finland. Not being entitled to work in the first place, they may eventually be lured into the grey market and paid a very low wage (see also Sigona 2012). Employers often promise to be able to legalise their stay through a low-paid job, but they remain undocumented, even if they are actually trying to work and become 'legal' through routes other than asylum.

For former asylum seekers (and thus for the current undocumented migrants of this study), 'residence permit' and 'asylum' were interchangeable words, as was apparent when talking with them. Their purpose, in most cases, was to be safe in Finland, and they did not distinguish between the different bureaucratic procedures. For them, words such as 'appeal', 'Administrative Court', 'Supreme Administrative Court', 'negative decision', and 'refusal of entry' were only technical terms. The former asylum seekers focused on finding ways to stay and avoid removal. We met many who did not know what to reply when we asked about their asylum process; one undocumented migrant replied: 'If I have appealed to a court? I don't know. I know that I don't receive services from the reception centre anymore; that I know'. As discussed in Chap. 2, asylum-related migrants often subjectively consider themselves to be refugees, although not all are official refugees from a legal perspective and according to the UN definition (see United Nations 1951).

Many of the survey respondents were not entirely aware whether they were still asylum seekers. They had submitted their asylum applications and received negative decisions from Migri, but they were not sure whether they had appealed against them in the Administrative Court, whether they had received second negative decisions from the Administrative Court, or whether they were trying to appeal to the Supreme Administrative Court (see Sect. 3.3.1). Some respondents had started a subsequent asylum application, but were not sure which stage it had reached. Overall, 27\% of the responding undocumented migrants said that they had received one negative decision on an asylum or residence permit application, $25 \%$ two negative decisions, $22 \%$ three negative decisions, and $21 \%$ four or more negative decisions. Undocumented migrants seemed not to know which stage their asylum processes had reached; they could remember how many negative decisions they had received, but not exactly from where. In addition, two out of three respondents (67\%) said that they had applied for residence permits (i.e. tried to remain in Finland through another 
process than asylum). No respondents had succeeded in their applications for asylum or a residence permit, so they were all undocumented migrants.

The general lack of clarity on the steps of the various bureaucratic asylum processes might negatively affect a migrant, resulting in him/her unwittingly making wrong choices and, thus, failing the asylum process and becoming undocumented. Additionally, the procedure requires that a person be able to make rational choices and understand the legal nuances, but this is often not the case, since many undocumented migrants have had traumatic experiences and are not capable of rationally acquiring and processing the amount of information required for the asylum process. They may or may not be aware of their precarious mental state, may lack the ability to ask for further clarification when needed, or may consider it an undignified act. In addition, scholars have noted how the inability to provide clear, organised, and classifiable reasons can lead to the rejection of an asylum request (Gill 2016). The migrants' lives and journeys often consist of dramatic events, non-linear decisions, incoherent actions, and unresolved psychological traumas (Bustamante et al. 2018; Carswell et al. 2011; Silove et al. 1997; Tedeschi 2021a); therefore, the legal requirements of clarity and consistency in the asylum process often clash with the reality of those migrants' lives (Crawley and Skleparis 2018; Feldman 2011).

The biggest obstacle for asylum seekers in the asylum process is passing the so-called asylum interview (see the following comment by an undocumented migrant). The international academic literature has highlighted the fact that asylum interviews are very stressful for the interviewees (Schock et al. 2015). It is the most important opportunity for them to show that they are persecuted in their country of origin and that they need international protection. One of the undocumented migrants commented:

\footnotetext{
During the Migri interview, I could not express myself. I felt like I could not reach out to them: that I could not explain myself, that I could not make myself understood. Now I have had this second negative decision, after only five days, because they don't believe that my sister, who is here with me, is my sister. They don't believe the documents I provided. I told them that they could do a DNA test to prove that my sister is my sister, but they don't want to. They say it is too expensive. The lawyer told me that he has now officially terminated his services. My sister has just made an appeal, but there is nothing left for me. I can be deported at any time. It is true, I didn't suffer any physical violence back in my home country, but my father was killed right in front of me, so I am terrified. I don't want to go back there.
}

During an asylum interview, an asylum seeker is required to tell his/her own story. The coherence and consistency of the story and the precise documentation of facts are elements that weigh considerably in Migri's final decision; however, in many cases, asylum seekers are not able to tell a coherent story-especially those who have had traumatic experiences and cannot recall all of the necessary details. In fact, detailed inspections of Migri's decisions (analysing the accuracy of translations, first-level decisions, and arguments for the decisions) identified cases in which the courts overruled Migri's rigid and narrow requirements regarding the comprehensive accuracy of the asylum seeker's narration of his/her journey to Finland and reasons for requesting asylum (see Migri 2018a). An incoherent or 
flawed story, even one containing evidence of persecution, can lead to a negative decision (Bögner et al. 2010; Schuster 2018; Shaw and Witkin 2004; Wilson-Shaw et al. 2012); thus, traumatic experiences can result in a person's status becoming illegal if he/she remains hidden in the country after the final negative asylum decision and the refusal of entry order are issued. Much more is involved in the bureaucratic procedures than the simple legal steps required to apply for asylum, apply for a residence permit, or legalise one's stay in the country. Cultural, physical, mental, and geographical barriers heavily influence the outcomes of bureaucratic procedures and determine the final result—such as obtaining a residence permit and the legal right to stay in Finland or becoming undocumented with no legal right to stay in the country. We are now going to present three cases drawn from the ethnographic fieldwork.

The first case concerns a family and it is emblematic of the asylum-seeking process. Originally, the family came from a country outside the EU (not named here for privacy and security reasons) and managed to obtain a residence permit for an EU member state. Initially, their reasons for leaving that EU member state and coming to Finland were unclear, but our chats indicated that the family feared something there. After months of conducting our field observations, their reasons for migrating to Finland seemed to be economic; however, their real motivation never emerged. When they arrived in Finland 10 years ago, they applied for asylum, even though they should not have done so when coming from another EU member state. They applied many times and failed. In the meantime, the husband managed to find a permanent job and applied for a residence permit in Finland, based on his work; however, because of their many failed asylum applications and the fact that they already had a residence permit in another EU member state, the husband did not receive a residence permit and was no longer allowed to work. They were told that they must go back to the EU member state from which they came. The husband did not seem to understand anything about this or a word of what his lawyer was telling him. He said that he only wanted to raise his children in Finland, find a job, and support his family. He did not understand 'why they were doing all this to me'. $\mathrm{He}$ repeatedly refused to accept the reality of being 'illegal' in Finland. For him, this formal decision did not mean anything, as his point was to stay in Finland and be allowed to live a normal life. The status of being illegal goes beyond clear-cut legal categories, comprising many in-between categories, everyday life circumstances, misunderstandings, and different mental states. Moreover, it is challenging to precisely trace and identify at what point in time a person finally becomes irregular in the country, particularly if he/she goes in and out of the asylum process many times, as happened to the above-mentioned family.

Another case concerned a young adult around 30 years old who had received a second negative decision on his asylum application from Migri. When his first negative decision arrived, he was not allowed to appeal, which is why he started a second asylum process from scratch; however, in the second decision, Migri concluded that he was abusing the system. According to Migri, he first 'disappeared' in Finland (apparently he did not go to the police to register his presence in the country, as he was requested to do) and in the subsequent interview, when asked 'With whom 
have you been in touch?', he could not answer, because he did not remember exactly whom he was in touch with in the city where he lived or the day centre he was frequenting. We knew him for a long time and became aware that, probably because of his traumatic past, he had trouble remembering things (in fact, many asylum seekers have challenges with memory after traumatic events; see Graham et al. 2014; Herlihy and Turner 2018; Herlihy et al. 2012); therefore, he could not properly reply to the migration officials' questions. Additionally, during the second interview, he mentioned a very short call he had with his mother, in which she said that he must not come back, because someone came looking for him at his home to take him away and kill him. The call was apparently short because his mother was very scared (she probably did not want to be traced), so he had no other details. He was very scared of being killed and, as a consequence, became anxious and stressed and could not sleep properly at night (he often fell asleep while talking with us). Nevertheless, the asylum process requires clear details, precise information, consistent stories (Van Liempt and Bilger 2018), and sound documents. The short call with his mother was not enough to demonstrate the real threat of persecution in his country of origin; therefore, he fell out of the asylum process again and became an undocumented migrant. His main fears were police and deportation (i.e. removal from Finland): he could no longer focus on the details of his asylum application. Ignoring everything else, he kept repeating that he did not want to go back to his country of origin. This example shows that a person who is under stress, or who does not fully understand what is required in the asylum process, might unwittingly make wrong decisions (such as failing to register with the police or not remembering details when requested), which will influence Migri's decision regarding his/her asylum.

The last case which we present clearly highlights the drawbacks of the legal/ illegal dichotomy. The person in question was a former asylum seeker who failed his asylum process, thus becoming an undocumented migrant. He said that there were problems in the translation and transcription of the asylum interview at Migri, as is common for many. He did not have the official documents required for international travel, and his country of origin's embassy in Finland would not issue travel documents or a passport for him; hence the police and border control authorities could not enforce refusal of entry and he could not be removed from Finland to his country of origin. This situation is common for people, especially those from Iraq, who are denied asylum in Finland (thus their entry into Finland is retroactively refused despite them already being in the country) and do not have a residence permit in Finland, but cannot be removed. The majority of them do not want to (and cannot) return voluntarily to their country of origin, so they remain in Finland, but with no access to health services (apart from emergency services) or formal entitlement to work. The blurred legal/illegal distinction is obvious here: the person is in Finland illegally, yet the authorities paradoxically know that he is in Finland and allow him/her to stay there. The last time we talked with him, he had managed to find work, albeit in the grey market. He said that, previously, his days all seemed the same, because he was not allowed to do anything: he was stuck in an unclear and unstable illegal/legal situation, in-between categories. The change cheered him up: even though it was an irregular, unregistered job, it gave him back his dignity. He 
said: 'I don't like to be like a beggar, but somehow my legal situation is forcing me to be one. This is why I am happy to work now!' The work made him feel better and also, to a certain extent, useful (see also Fleay and Hartley 2016).

\subsection{The Status of Asylum Seekers and Undocumented Migrants in Finland}

In Sects. 3.2 and 3.3, we explained how several asylum seekers became undocumented migrants in Finland. In early 2019, about 10,000 asylum seekers and about 4000-4500 undocumented migrants were known to be in Finland, where, as in many other countries in the EU, one trajectory to becoming an undocumented migrant was through the asylum process. In the autumn of 2019, of around 10,000 asylum seekers, about 1500 were waiting to receive their first asylum decisions from the authorities, more than 1000 were awaiting the authorities' decisions on their subsequent asylum applications, and 3600-4000 were waiting for court decisions. The court had ordered Migri to re-process the asylum decisions of 2200-3000 asylum seekers; roughly 600 had obtained a residence permit, but had not yet registered with any municipality (which is compulsory); and 200 former asylum seekers were awaiting their removal from Finland (Kosonen 2019). As these numbers and Sects. 3.2 and 3.3 indicate, the asylum process is complex and consists of various stages.

A particularity among undocumented migrants in Finland is the large number of male Iraqi asylum seekers. According to Migri, in 2015-2018, adult Iraqi men made about 30,000 (precisely 29,577) asylum applications; furthermore, 7266 male Iraqi children (unaccompanied minors and those with families) asked for asylum. Of Iraqi male applicants (including children), 3096 (8.4\%) received asylum, and 954 (2.6\%) were granted secondary protection. Of their applications, $1836(5.0 \%)$ were not inspected (due to the Dublin Regulation or due to obvious grounds resulting in the non-processing of the application). Of the Iraqi male applicants, 10,648 (28.9\%) received negative asylum decisions. These numbers, however, also include people who made second applications on modified grounds. Of the applicants, 20,309 left the asylum process before completing it, disappeared from the authorities, or were still going through the process in 2019.

Another rough estimate is that, of 20,000 Iraqi male individuals who applied for asylum in Finland in 2015-2018, about 3500 (18\%) obtained asylum, 800 (4\%) received residence permits through secondary protection, $2000(10 \%)$ obtained residence permits by other means, and 13,700 (69\%) did not receive residence permits, with or without asylum, subsidiary protection, for humanitarian reasons, or on other grounds. There is no information on how many of the Iraqi male asylum seekers left Finland during the process or after receiving the final negative decisions on their applications. The Finnish authorities estimate that about 5300 Iraqi men (27\% of asylum applicants) did not follow through with the asylum process 
(included in the previous number who did not obtain residence permits); for example, they did not register at a reception centre, did not receive the allowance for asylum seekers, or did not attend an asylum interview. This group disappeared from the authorities during the asylum process before receiving the final decisions on their applications. This does not mean that all of them left Finland, but many did. Of the male asylum seekers from Iraq, some have utilised the voluntary return mechanism and hundreds have been forcedly removed by the Finnish authorities; therefore, it is evident that Iraqi men constitute the largest group of undocumented migrants in Finland.

A peculiarity of asylum applications emerged with the COVID-19 pandemic. In 2019, 4550 asylum applications were presented in Finland, of which 56\% were new applications and $44 \%$ were subsequent asylum applications that former asylum seekers had made after receiving a negative final decision from Migri or an administrative court on an earlier application. To present subsequent applications, these people either had to reside in Finland or leave Finland shortly after receiving the decisions. On average, in 2019, 379 asylum applications were presented monthly, of which 211 were new and 168 subsequent applications; however, the situation changed dramatically in 2020 due to measures to prevent the COVID-19 pandemic. From April to September 2020 (a 6-month period), on average, 245 asylum applications were presented monthly, of which $87(36 \%)$ were new and 158 (64\%) were subsequent applications (Migri 2020); thus, the decreases of applications in the first 6 months of the pandemic were 59\% for new applications, $6 \%$ for subsequent applications, and 35\% for all applications. Restrictions on international travel caused a rapid and substantial reduction of new asylum seekers; however, the pandemic had very little impact on the number of subsequent applications. Of the new applications, $53 \%$ were presented by adults alone, $20 \%$ by minors accompanied by family, and $27 \%$ by unaccompanied minors (Migri 2020). Overall, in the autumn of 2020, there were asylum seekers from 70 countries in Finland (plus stateless people and those of unclear origin), of which the largest group (34\%) came from Iraq, followed by groups from Somalia (17\%), Afghanistan (14\%), the Russian Federation (5\%), Turkey (4\%), Iran (3\%), and Syria (2\%). The majority were 18-34-year-old men (Migri 2020).

When the asylum process is completed, former asylum seekers lose their right to reside in reception centres, the monthly allowance (315 EUR, or 92 EUR if food is provided) they receive to survive, and access to extended health services (not only emergency health services, but any health services they need according to the reception centres), and many other services. As mentioned, undocumented migrants have a constitutional right to emergency health services, although many experience challenges in accessing it (see Sect. 5.3). In addition, the social welfare system should give them some support if they are in need and can prove that they live in Finland. Proving that is difficult, however, because they seldom have a formally registered address in a municipality and, if they provide one, the police and enforcement authorities could trace them. In addition, completing the application forms for social benefits is very difficult, even if a person is proficient in Finnish, Swedish, or 
English. Nevertheless, these and some other basic services are, in principle, available.

Eventually, many undocumented migrants go into hiding to avoid being apprehended by the police or other authorities and continue to live outside the formal social systems. With tightening policies, undocumented migrants are then pushed deeper into the margins, increasing their risk of experiencing serious problems, including human trafficking, the grey economy, social exclusion, and insecurity (Faist 2018). This is not only a concern in Finland, but has been widely analysed in the international academic literature in relation to undocumented migrants' inclusion/exclusion (Ambrosini 2013), marginalisation from society (Engbersen and Broeders 2009), vulnerability (Düvell et al. 2010), exploitation (Salt and Stein 1997), and utilisation of unofficial networks (Ambrosini 2017), to cite but a few topics.

In Finland, the numbers of asylum seekers in 2018 and 2019 were much lower than the pre-2015 numbers (Migri 2018c; see also Fig. 1.1 in Sect. 1.3). This reduction was caused by asylum seekers' restricted access to the EU, increased constraints on asylum-related migrants' movements within the EU (i.e. they are effectively registered in the first country of their arrival in the EU, which is rarely Finland), and Finland's stricter asylum policies. Finland no longer grants the aliens' passports to asylum seekers that would facilitate the acquisition of valid passports for their citizenships, which are prerequisites for obtaining permanent residence in Finland. Furthermore, asylum seekers must withdraw their asylum applications if they apply for residence permits for study, work, or family reasons. The Finnish authorities may then suspect that these people used the asylum application only to gain legal entry into Finland, but did not actually have asylum grounds, because their intention was to study or work in Finland. In addition, while waiting for such residence permits, they are not allowed to work in Finland. As mentioned previously, in 2020, the COVID-19 pandemic resulted in lockdowns and substantial reductions in travel, including that of asylum-related migrants to the EU (see Jauhiainen 2020). In Finland, as in many other EU member states, the number of new asylum applications declined substantially, commensurate with the development of the pandemic in 2020 (Migri 2020).

At the same time, the number of undocumented migrants increased in Finland, especially those people who applied for asylum in Finland in 2015. The final decisions on asylum in Finland are usually made 1 to 3 years after a person requests asylum. The large absolute number of asylum applications in 2015 led to a growing number of people being granted asylum and residence permits, but also a substantially higher number of rejected asylum applications. The majority of asylum applications did not result in the applicants being granted the right to remain in Finland.

Migri grants very few first-time applicants refugee status. In 2015-2018, Migri made approximately 51,500 asylum application decisions. Of these, approximately $31 \%$ (about 16,100) were positive-that is, the applicants were granted residence permits for Finland on the grounds of international protection (refugees; about two-thirds of the cases) or for other, usually humanitarian, reasons (about 
one-third of cases). Approximately 12\% (about 6000) of the decisions related to so-called Dublin Regulation cases (in which the people had applied for, or received, asylum in another EU member state), so the Finnish authorities did not inspect these applications, according to EU rules. Approximately 16\% (about 7400-8000) of the decisions were based on incomplete asylum processes: they were unfinished because the applicants did not follow the process correctly (for example, did not appear for their Migri interviews), left the country, or withdrew their applications. Of the decisions, approximately $42 \%$ (about 21,700) were negative, meaning that Migri decided that the applicant would not be given a residence permit in Finland for asylum or humanitarian reasons. From 2015-2018, of the negative decisions on asylum applications by Migri leading to refusal of entry into Finland, 59\% pertained to applications made by Iraqi nationals, $17 \%$ Afghani nationals, 6\% Somali nationals, and $18 \%$ other nationals (Migri 2019i). In general, approximately $70 \%$ of the applicants were not given the right to reside in Finland; however, of the EU appellate court decisions in 2018, Finland had relatively the largest number (68\%) of decisions that led to asylum, subsidiary protection, or residence permits granted for humanitarian reasons (Eurostat 2019). Migri agreed that it was not prepared to handle the huge volume of asylum applications after 2015 (Migri 2018a), which resulted in cases in which court decisions differed from Migri's initial decisions.

Locally, undocumented migrants' situations are also very complex. In 2017, 38 Finnish municipalities (12\% of all municipalities in the country), and in 2018, 42 Finnish municipalities (14\%), mentioned that they had undocumented migrants (Jauhiainen and Gadd 2019; Jauhiainen et al. 2018); however, undocumented migrants in Finland are largely an urban phenomenon. In general, the larger a municipality's population is, the more probable it is that undocumented migrants live there. Of the cities and towns in Finland with more than 100,000 inhabitants, $78 \%$ were known to harbour undocumented migrants; by contrast, they were found in only $5 \%$ of rural municipalities and in $4 \%$ of municipalities with less than 10,000 inhabitants. There was thus a clear correlation between the size of municipalities' populations and the presence of undocumented migrants in those municipalities $(\mathrm{p}=0.000)$. Similarly, the more urban the character of the municipality (from the categories fully 'urban', 'mostly urban', 'some urban', and 'rural'), the more likely there were to be undocumented migrants $(\mathrm{p}=0.000)$. Discounting population size, whether the majority of the population in a municipality spoke Finnish or Swedish (since there are municipalities in Finland where Swedish is the language of the majority population) made no difference regarding the presence of undocumented migrants; however, there was a clear correlation between the existence of an asylum seeker reception centre and the existence of undocumented migrants in these municipalities $(\mathrm{p}=0.000)$. Many reception centres are also located in larger municipalities, and most undocumented migrants lived in Finland's largest cities (Jauhiainen and Gadd 2019; Jauhiainen et al. 2018). With the exception of Helsinki, which has 700,000 inhabitants, the remaining cities in Finland are rather small: five cities have around 200,000-350,000 inhabitants and, in total, nine cities have more than 100,000 inhabitants. In 2017, $86 \%$ of municipalities had no evidence of undocumented migrants, according to the local authorities or NGOs dealing with 
undocumented migrants there. Obviously, it was possible that there might be undocumented migrants in some of the 267 municipalities that claimed not to have any; however, most of these municipalities are very small, remote, and located in the eastern and northern parts of Finland, where the presence of any foreign nationals would definitely be noted. Some municipalities clearly mentioned that undocumented migrants were not present, and never would be, in their municipalities.

Complexity at the local level also relates to the provision of services, which vary from one municipality to another. As mentioned, the Constitution guarantees emergency healthcare services for anyone in Finland, undocumented migrants included (for a broader discussion about healthcare, see Chap. 5). These services are heavily subsidised by the public sector, but some costs are borne by users. If a client cannot afford the provided service, the local authority is responsible for paying for it. Some (often small) municipalities do not want to allocate money from their limited budgets for undocumented migrants, so they are reluctant to provide such services and encourage the migration of undocumented people to larger cities. In reality, the services (both healthcare and others, such as accommodation) vary substantially between neighbouring municipalities. In addition, earlier studies indicated differences both between countries and within countries (e.g. between municipalities) in how undocumented migrants are dealt with (Woodward et al. 2014).

Local authorities can voluntarily extend their service provision to undocumented migrants, but in principle, local authorities have to cover the associated costs. In November 2017, because of the increase of undocumented migrants in Helsinki, the city's politically elected local council made the decision-after a heated debate and voting - to provide necessary healthcare to undocumented migrants in addition to emergency healthcare (Jauhiainen et al. 2018). Later, a few other municipalities in Finland adopted this approach and gave undocumented migrants similar rights to such extended services. Some local municipalities, NGOs, and other actors also provided services other than healthcare. Helsinki later implemented a stricter policy, asking undocumented migrants to prove that they lived in Helsinki or were registered there previously as asylum seekers (see Chap. 5).

In Finland, although certain local NGOs consider undocumented migrants to have full 'right to the city' (Lefebvre 1968), the central government and immigration laws categorise them as illegal, with no rights to the city, and for this reason feel bound to expel them as soon as they are denied asylum. Simultaneously, the language the media uses to describe undocumented migrants' deeds exposes them to a negative social and legal super-visibility (Brighenti 2010), whereby everything they do 'becomes gigantic to the point that it paralyses' (Brighenti 2007: 330) any action they might perform, at the same time triggering fear and suspicion among citizens; thus, undocumented migrants can easily become synonymous with crime, danger, sickness, suspicion, fear, threats to security, and so on.

Undocumented migrants react in various ways to their precarious, unstable situations. Some have become proactive people in such a positive way that local residents eventually fight for their right to reside (this has happened in a few small villages and in at least one medium-sized town in Finland; Tedeschi and Gadd 2021). Some are able to negotiate relationships with people they trust from their 
community, NGOs, and even the police, in that, if they do not create any trouble, they are informally allowed to stay. Hospitals can provide urgent healthcare for undocumented migrants without asking for further information, thus accepting their anonymity. However, the COVID-19 pandemic created an additional challenge for undocumented migrants wishing to remain anonymous, but needing to contact health authorities due to possible COVID-19 symptoms. Some local municipalities also provide basic assistance to guarantee undocumented migrants' livelihoods (for instance, shelter from cold weather) and provide access to schools, since all children are by law entitled to receive basic compulsory education. Other undocumented migrants (actually, the majority of them) are too scared to use these services and therefore choose to remain hidden. In fact, of the undocumented migrants responding to our survey, the majority $(60 \%)$ felt stuck in their current life situations, $24 \%$ did not know how to answer this question, and only one out of six (16\%) disagreed about feeling stuck. While staying outside official administrative systems offers protection from deportation (Battistella 2017), it also opens up the alreadymentioned high risks of exploitation, marginalisation, and even serious health and security issues.

\subsection{Conclusions}

Becoming and being an undocumented migrant is a complex process in Finland. One person can have a temporary legal right to reside in Finland, but lose this right and consequently become an undocumented migrant. Another person might never have the right to reside in Finland. If a person does not have the right to enter Finland at all, then the legal procedure is to expel him/her, either by denying the right to enter or the police removing him/her from Finland. If a person has an expired residence permit, then the legal procedure is to expel him/her by deportation. Migri makes the decisions about people's right to reside in Finland, but its decisions can be appealed against in the Administrative Court and the Supreme Administrative Court, whose decisions Migri must abide by. Ultimately, the police are the enforcement authority responsible for expelling people with no right to reside in Finland.

There are many ways to become an undocumented migrant in Finland. Since 2015, the most typical way has been to ask for asylum, then be rejected, but to continue to remain in the country despite an order to leave Finland. The legal asylum application procedure is logical, but in practice, very complex; many asylum seekers do not understand the process or what is and could be relevant to their claims for asylum. Facing the fear of potentially being deported, some asylum seekers have converted, or claimed to have converted, from Islam to Christianity or have claimed homosexuality to give their asylum applications further grounds. In some cases the claim is not made just out of fear of deportation, but it is actually genuine, and Migri has then the difficult task to judge the truthfulness of these claims.

As for how the asylum process is experienced by former asylum seekers, now undocumented migrants, we showed that asylum seekers did not fully understand the 
asylum process. Some asylum seekers' traumatic pasts negatively influenced their asylum interviews, which required consistent, coherent, and flawless narration, and often full documentation of their personal stories. Misunderstanding of the asylum procedures led some asylum seekers to make wrong choices, which then influenced the final asylum decisions; thus, they became undocumented migrants despite their genuine need to be protected. The dichotomy of illegal/legal migrant no longer applies to the real lives of these people, who live in the grey zone of being undocumented. In Finland, some asylum seekers were not granted asylum, yet, their expulsion could not be enforced because they lacked the necessary travel documents or their countries of origin refused to take them back.

\section{References}

Ambrosini, M. (2013). 'We are against a multi-ethnic society': Policies of exclusion at the urban level in Italy. Ethnic and Racial Studies, 36(1), 136-155.

Ambrosini, M. (2017). Why irregular migrants arrive and remain: The role of intermediaries. Journal of Ethnic and Migration Studies, 43(11), 1813-1830.

Ambrosini, M. (2018). Irregular immigration in Southern Europe. Actors, dynamics and governance. Cheltenham: Palgrave Macmillan.

Anderson, B., \& Ruhs, M. (2010). Researching illegality and labour migration. Population, Space and Place, 16, 175-179.

Andersson, L., Hjern, A., \& Ascher, H. (2018). Undocumented adult migrants in Sweden: Mental health and associated factors. BMC Public Health, 18(1369).

Battistella, G. (2017). From invisibility to recognition: Reflections on the conditions of migrants in our society. Keynote address delivered at Exodus V, Scalabrini Migration Center, Singapore, August 31 - September 3. Available at: http://cmsny.org/publications/invisibility-recognition/. Accessed 23 Mar 2019.

Black, R. (2003). Breaking the convention: Researching the 'illegal' migration of refugees to Europe. Antipode, 35, 34-54.

Bögner, D., Brewin, C., \& Herlihy, J. (2010). Refugees' experiences of Home Office interviews: A qualitative study on the disclosure of sensitive personal information. Journal of Ethnic and Migration Studies, 36(3), 519-535.

Brighenti, A. (2007). Visibility. A category for the social sciences. Current Sociology, 55(3), 323-342.

Brighenti, A. (2010). Visibility in social theory and social research. Basingstoke/New York: Palgrave Macmillan.

Bustamante, L., Cerqueira, R., Leclerc, E., \& Brietzke, E. (2018). Stress, trauma, and posttraumatic stress disorder in migrants: A comprehensive review. Revista Brasileira de Psiquiatria, 40(2), 220-225.

Carswell, K., Blackburn, P., \& Barker, C. (2011). The relationship between trauma, post-migration problems and the psychological well-being of refugees and asylum seekers. International Journal of Social Psychiatry, 57(2), 107-119.

Crawley, H., \& Skleparis, D. (2018). Refugees, migrants, neither, both: Categorical fetishism and the politics of bounding in Europe's 'migration crisis'. Journal of Ethnic and Migration Studies, 44(1), 48-64.

Czaika, M., \& Hobolt, M. (2016). Do restrictive asylum and visa policies increase irregular migration into Europe? European Union Politics, 17(3), 345-365.

De Haas, H., Natter, K., \& Vezzoli, S. (2016). Growing restrictiveness or changing selection? The nature and evolution of migration policies. International Migration Review, 1-44. 
Dekker, R., \& Engbersen, G. (2014). How social media transform migrant networks and facilitate migration. Global Networks, 14, 401-418.

Düvell, F. (Ed.). (2006). Illegal immigration in Europe. Beyond control? Basingstoke/New York: Palgrave Macmillan.

Düvell, F. (2008). Clandestine migration in Europe. Social Science Information, 47(4), 479-497.

Düvell, F. (2011). Paths into irregularity: The legal and political construction of irregular migration. European Journal of Migration and Law, 13(3), 275-295.

Düvell, F., Triandafyllidou, A., \& Vollmer, B. (2010). Ethical issues in irregular migration research in Europe. Population, Space and Place, 16, 227-239.

Engbersen, G., \& Broeders, D. (2009). The state versus the alien: Immigration control and strategies of irregular immigrants. West European Politics, 32(5), 867-885.

Eurostat. (2019). Asylum statistics 2019. https://ec.europa.eu/eurostat/statistics-explained/index. php/Asylum_statistics

Faist, T. (2018). The moral policy to force migration. Ethnic and Racial Studies, 41(3), 412-423.

Fassin, D. (2013). The precarious truth of asylum. Public Culture, 25(69), 39-63.

Feldman, G. (2011). The migration apparatus: Security, labour, and policymaking in the European Union. Stanford: Stanford University Press.

Finnish Red Cross. (2019). Questions and answers about asylum seekers and reception centers. Available at: https://www.redcross.fi/node/16512/qa-asylum-seekers-and-reception-centers. Accessed 10 Sept 2019.

Fleay, C., \& Hartley, L. (2016). 'I feel like a beggar': Asylum seekers living in the Australian community without the right to work. Journal of International Migration \& Integration, 17(4), 1031-1048.

Gadd, K., \& Lehtikunnas, L. (2019). Asylum interview as a fork on the road - From asylum seeker to irregular migrant. In C. Pracana \& M. Wang (Eds.), Psychological applications and trends 2019 (pp. 212-216). Lisbon: InScience Press.

Gibney, M. (2004). The ethics and politics of asylum: Liberal democracy and the response to refugees. Cambridge: Cambridge University Press.

Gill, N. (2016). Nothing personal? Geographies of governing and activism in the British asylum system. Chichester: Wiley.

Goldring, L., \& Landolt, P. (2013). The conditionality of legal rights and status: Conceptualising precarious non-citizenship. In L. Goldring \& P. Landolt (Eds.), Producing and negotiating non-citizenship: Precarious legal status in Canada (pp. 3-27). Toronto: University of Toronto Press.

Gonzales, R. (2016). Lives in Limbo: Undocumented and coming of age in America. Oakland: University of California Press.

Government of Finland. (2019). Inclusive and competent Finland - A socially, economically and ecologically sustainable society. Programme of Prime Minister Antti Rinne's Government 2019. Helsinki: The Prime Minister's Office.

Graham, B., Herlihy, J., \& Brewin, C. (2014). Overgeneral memory in asylum seekers and refugees. Journal of Behavior Therapy and Experimental Psychiatry, 45(3), 375-380.

Herlihy, J., \& Turner, S. (2018). Legal and ethical considerations related to the asylum process. In N. Morina \& A. Nickerson (Eds.), Mental health of refugee and conflict-affected populations (pp. 305-324). Cham: Springer.

Herlihy, J., Jobson, L., \& Turner, S. (2012). Just tell us what happened to you: Autobiographical memory and seeking asylum. Applied Cognitive Psychology, 26, 661-676.

International Organisation for Migration. (2018). Irregular migration. Migration data portal. Available at: https://migrationdataportal.org/?i=stock_abs_\&t=2017. Accessed 14 June 2019.

Jauhiainen, J. (2017). Asylum in Finland? The 2015 asylum seekers and the asylum processes in Finland. In J. Jauhiainen (Ed.), Turvapaikka Suomesta? Vuoden 2015 turvapaikanhakijat ja turvapaikkaprosessit Suomessa (pp. 157-172). Turku: Publications of the Department of Geography and Geology of the University of Finland 5. 
Jauhiainen, J. (2020). Biogeopolitics of Covid-19: Asylum-related migrants at the European Union borderlands. Tijdschrift voor Economische en Sociale Geografie, 111(3), 260-274.

Jauhiainen, J., \& Gadd, K. (2019). Paperittomat Suomessa vuoden 2018 alussa [In Finnish, Undocumented migrants in Finland in the beginning of 2018]. URMI Kaupunkianalyyseja III. Available at: https://urmi.fi/portfolio/paperittomat-suomessa-vuoden-2018-alussa/. Accessed 6 Sept 2019.

Jauhiainen, J., Gadd, K., \& Jokela, J. (2018). Paperittomat Suomessa 2017 [In Finnish, Undocumented migrants in Finland in 2017]. Turku: Publications of the Department of Geography and Geology of the University of Finland 8.

Jauhiainen, J., Eichholz, L., \& Spellerberg, A. (2019). Refugees, asylum seekers and undocumented migrants in Germany, 2019. The case of the Rhineland-Palatinate and Kaiserslautern. Turku: Publications of the Department of Geography and Geology of the University of Turku 13.

Jokinen, A. (2017). Police statistics of persons found residing illegally in Finland. Personal information received on 5.1.2017.

Kälin, W. (1986). Troubled communication: Cross-cultural misunderstandings in the asylumhearing. International Migration Review, 20(2), 230-241.

Koivula, T. (2020). Poliisin paperittomiin kohdistamat toimenpiteet. Eri poliisilaitosten toimenpiteet paperittomien kohtaamisessa ja käsittelyssä [In Finnish, Police measures against the paperless migrants. Measures taken by various police departments in dealing with and handling the paperless migrants]. Poliisiammattikorkeakoulun opinnäytetyö, Helsinki.

Könönen, J. (2018). Border struggles within the state: Administrative bordering of non-citizens in Finland. Nordic Journal of Migration Research, 8(3), 143-150.

Könönen, J. (2020). Legal geographies of irregular migration: An outlook on immigration detention. Population, Space and Place, 26, e2340.

Kosonen, P. (2019). 'Tuntuu, että en jaksa enää', sanoo paperiton Aljoarin Adnan - Paperittomia löydetään koko ajan lisää Suomesta [In Finnish, 'I feel like I can’t take it anymore', says paperless Aljoarin Adnan - More paperless people are always being found in Finland]. Available at: https://yle.fi/uutiset/3-10921851. Accessed 23 Apr 2020.

Lefebvre, H. (1968). Le Droit à la Ville [In French, The right to the city]. Paris: Anthropos.

Lepola, O. (2018). Turvapaikanhakijat oikeusavun asiakkaina. [In Finnish, Asylum seekers as clients of legal aid] Valtioneuvoston Selvitys- ja Tutkimustoiminta Policy Brief 33/2018.

Leurs, K., \& Ponzanesi, S. (2018). Connected migrants: Encapsulation and cosmopolitanisation. Popular Communication, 16(1), 4-20.

Lewis, H., Dwyer, P., Hodkinson, S., \& Waite, L. (2015). Hyper-precarious lives. Migrants, work and forced labour in the Global North. Progress in Human Geography, 39(5), 580-600.

Mac an Ghaill, M., Brah, A., \& Hickman, M. (2000). Thinking identities: Ethnicity, racism and culture. London: Macmillan.

Maslowski, S. (2015). The expulsion of European Union citizens from the host member state: Legal grounds and practice. Central and Eastern European Migration Review, 4(2), 61-85.

McAuliffe, M., \& Koser, K. (Eds.). (2017). A long way to go. Irregular migration patterns, processes, drivers and decision-making. Canberra: ANU Press.

Menjívar, C. (2006). Liminal legality: Salvadoran and Guatemalan immigrants' lives in the United States. American Journal of Sociology, 111(4), 999-1037.

Migration and Home Affairs. (2019). Who qualifies for international protection. Available at: https://ec.europa.eu/home-affairs/what-we-do/policies/asylum/refugee-status_en. Accessed 12 Sept 2019.

Migri. (2017). How does converting to Christianity affect asylum applications? Available at: https://migri.fi/en/article/-/asset_publisher/miten-kristinuskoon-kaantyminen-vaikuttaaturvapaikkapaatokseen. Accessed 23 Mar 2019.

Migri. (2018a). Maahanmuuttoviraston selvitys sisäministerille turvapaikkapäätöksentekoon ja -menettelyyn liittyen [In Finnish, Report of the Finnish Immigration Service to the Minister of the Interior regarding asylum decision-making and procedure]. Helsinki: Migri. 
Migri. (2018b). At the moment about every second asylum application is a subsequent application. Available at: https://migri.fi/en/article/-/asset_publisher/turvapaikkahakemuksista-noin-puoleton-talla-hetkella-uusintahakemuksia. Accessed 23 Mar 2019.

Migri. (2018c). Statistics for 2017: Clearly less asylum seekers than the year before - Over 2,100 asylum seekers submitted their first application. Available at: https://migri.fi/en/article/-/asset_ publisher/vuoden-2017-tilastot-turvapaikanhakijoita-selvasti-edellisvuosia-vahemmanensimmaisen-hakemuksen-jatti-reilut-2-100-hakijaa. Accessed 14 June 2019.

Migri. (2018d). Voluntary return supports the future of asylum seekers in their home country. Available at: https://migri.fi/en/article/-/asset_publisher/vapaaehtoinen-paluu-tukeeturvapaikanhakijan-tulevaisuutta-kotimaassa. Accessed 6 Mar 2019.

Migri. (2019a). Appealing a decision. Available at: https://migri.fi/en/negative-decision/appealinga-decision. Accessed 23 Mar 2019.

Migri. (2019b). Applying for asylum. Available at: https://migri.fi/en/applying-for-asylum. Accessed 29 Apr 2019.

Migri. (2019c). Legal advice. Available at: https://migri.fi/en/legal-advice. Accessed 29 Apr 2019.

Migri. (2019d). Negative decision. Available at: http://migri.fi/en/asylum-in-finland/negativedecision. Accessed 23 Mar 2019.

Migri. (2019e). Refusal of entry. Available at: https://migri.fi/en/refusal-of-entry. Accessed 23 Mar 2019.

Migri. (2019f). Refusal of entry and deportation. Available at: https://migri.fi/en/refusal-of-entryand-deportation. Accessed 23 Mar 2019.

Migri. (2019g). Residence permit. Available at: https://migri.fi/en/residence-permit. Accessed 10 Sept 2019.

Migri. (2019h). Right to work. Available at: https://migri.fi/en/asylum-seeker-s-right-to-work. Accessed 29 Apr 2019.

Migri. (2019i). Statistics. Available at: https://tilastot.migri.fi/index.html\#decisions?l=en. Accessed 10 Sept 2019.

Migri. (2019j). What are the grounds for asylum? Available at: https://migri.fi/en/what-are-thegrounds-for-asylum. Accessed 29 Apr 2019.

Migri. (2019k). When is an application not processed in Finland? Available at: https://migri.fi/en/ when-is-an-application-not-processed-in-finland. Accessed 29 Apr 2019.

Migri. (2020). Statistics on international protection. Available at: https://tilastot.migri.fi/ \#applications/23330. Accessed 13 Oct 2020.

Ministry for Foreign Affairs. (2019). European court of human rights gives judgment concerning Finland in the case of the return of an asylum seeker to Iraq. Press Release 14.11.2019. https:// valtioneuvosto.fi/en/article/-/asset_publisher/european-court-of-human-rights-gives-judgmentconcerning-finland-in-the-case-of-the-return-of-an-asylum-seeker-to-iraq. Accessed 14 Nov 2019

Ministry of the Interior of Finland. (2011). Finnish act on the reception of persons applying for international protection. Available at: https://www.finlex.fi/en/. Accessed 29 Apr 2019.

Ministry of the Interior of Finland. (2018a). International migration 2017-2018 - Report for Finland. Ministry of the Interior: Helsinki.

Ministry of the Interior of Finland. (2018b). The fight against illegal immigration requires cooperation between authorities. Available at: https://intermin.fi/en/areas-of-expertise/migration/ combating-illegal-immigration. Accessed 25 Mar 2019.

Ministry of the Interior of Finland. (2019). Assisted voluntary return provides the opportunity to start a new life in the home country. Available at: https://intermin.fi/en/areas-of-expertise/ migration/voluntary-and-forced-return. Accessed 3 May 2019.

Niemann, A., \& Zaun, N. (2018). EU refugee policies and politics in the times of crisis: Theoretical and empirical perspective. Journal of Common Market Studies, 56(1), 3-22.

O'Reilly, Z. (2018). 'Living liminality': Everyday experiences of asylum seekers in the 'direct provision' system in Ireland. Gender, Place \& Culture, 25(6), 821-842. 
Orrenius, P., \& Zavodny, M. (2016). Irregular immigration in the European Union (Working Paper 1603). Dallas: Federal Reserve Bank of Dallas.

Puumala, E., Ylikomi, R., \& Ristimäki, H. (2018). Giving an account of persecution: The dynamic formation of asylum narratives. Journal of Refugee Studies, 31(2), 197-215.

Queiroz, B. (2018). Illegally staying in the EU. An analysis of illegality in EU migration. Oxford: Hart Publishing.

Salt, J., \& Stein, J. (1997). Migration as a business: The case of trafficking. International Migration, $35,467-494$.

Sarausad, M. (2019). Bordering and the grey area in the binary classifications of migrants within migration regimes. Migration and Development, 8(1), 25-36.

Schittenhelm, K. (2019). Implementing and rethinking the European Union's asylum legislation: The asylum procedures directive. International Migration, 57, 229-244.

Schock, K., Rosner, R., \& Knaevelsrud, C. (2015). Impact of asylum interviews on the mental health of traumatised asylum seekers. European Journal of Psychotraumatology, 6(1), 26286.

Schuster, L. (2018). Fatal flaws in the UK asylum decision-making system: An analysis of Home Office refusal letters. Journal of Ethnic and Migration Studies, 46(7), 1371-1387.

Schweitzer, R. (2017). Integration against the state: Irregular migrants' agency between deportation and regularisation in the United Kingdom. Politics, 37(3), 317-331.

Shaw, J., \& Witkin, R. (2004). Get it right. How home office decision making fails refugees. A report from Amnesty International UK. London, Amnesty International United Kingdom.

Sigona, N. (2012). 'I have too much baggage': The impacts of legal status on the social worlds of irregular migrants. Social Anthropology, 20, 50-65.

Silove, D., Sinnerbrink, I., Field, A., Manicavasagar, V., \& Steel, Z. (1997). Anxiety, depression and PTSD in asylum-seekers: Associations with pre-migration trauma and post-migration stressors. British Journal of Psychiatry, 170(4), 351-357.

Tedeschi, M. (2021a). On the ethical dimension of irregular migrants' lives: Affect, becoming and information. Dialogues in Human Geography, 11(1), 44-63.

Tedeschi, M. (2021b). Negotiating survival needs with ontological in/visibility: An ethnographic exploration of irregular migrants' lawscapes in Finland (Submitted manuscript).

Tedeschi, M., \& Gadd, K. (2021). On multiple spacetimes in the everyday lives of irregular migrants in Finland. The Geographical Journal (online first).

Thomsen, T., \& Jørgensen, M. (2012). Researching irregular migration. Concepts, numbers, and empirical findings in a Scandinavian context. Nordic Journal of Migration Research, 2(4), 275-279.

Triandafyllidou, A. (Ed.). (2016). Irregular migration in Europe: Myths and realities. London: Routledge.

Triandafyllidou, A., \& Vogel, D. (2010). Irregular migration in the European Union: Evidence, facts and myths. In A. Triandafyllidou (Ed.), Irregular migration in Europe. Myths and realities (pp. 291-300). London: Routledge.

Tsoni, I. (2016). 'They won't let us come, they won't let us stay, they won't let us leave'. Liminality in the Aegean borderscape: The case of irregular migrants, volunteers and locals on Lesvos. Human Geography, 9(2), 35-46.

United Nations. (1951). Text of the 1951 convention relating to the status of refugees. Resolution 2198 (XXI) by the United Nations General Assembly.

Van Liempt, I., \& Bilger, V. (2018). Methodological and ethical dilemmas in research among smuggled migrants. In R. Zapata-Barrero \& E. Yalaz (Eds.), Qualitative research in European migration studies (IMISCOE research series) (pp. 269-285). Cheltenham: Springer.

Wilson-Shaw, L., Pistrang, N., \& Herlihy, J. (2012). Non-clinicians' judgments about asylum seekers' mental health: How do legal representatives of asylum seekers decide when to request medico-legal reports? European Journal of Psychotraumatology, 3(1), 18406.

Woodward, A., Howard, N., \& Wolffers, I. (2014). Health and access to care for undocumented migrants living in the European Union: A scoping review. Health Policy and Planning, 29(7), 818-830. 
Yle.fi. (2018). Asylum seeker killed in Iraq weeks after repatriation from Finland. Available at: https://yle.fi/uutiset/osasto/news/asylum_seeker_killed_in_iraq_weeks_after_repatriation_ from_finland/10071096. Accessed 10 Sept 2019.

Yle.fi. (2019a). Finland doubles assistance to encourage voluntary repatriation. Available at: https://yle.fi/uutiset/osasto/news/finland_doubles_assistance_to_encourage_voluntary_repatria tion/10626337. Accessed 10 Sept 2019.

Yle.fi. (2019b). Lentolippu Irakiin ja 5000 euroa päälle? Suomi tarjoaa turvapaikanhakijoille yhä enemmän rahaa, jotta he poistuisivat maasta. [In Finnish, One way flight ticket to Iraq and on top 5,000 euro? Finland is offering more and more money to asylum seekers to leave the country]. Available at: https://yle.fi/uutiset/3-10614021. Accessed 21 Apr 2020.

Yle.fi. (2020). Finnish police believe asylum seeker staged his own death after returning to Iraq. Available at: https://yle.fi/uutiset/osasto/news/finnish_police_believe_asylum_seeker_staged_ his_own_death_after_returning_to_iraq/11318962. Accessed 23 Apr 2020.

Open Access This chapter is licensed under the terms of the Creative Commons Attribution 4.0 International License (http://creativecommons.org/licenses/by/4.0/), which permits use, sharing, adaptation, distribution and reproduction in any medium or format, as long as you give appropriate credit to the original author(s) and the source, provide a link to the Creative Commons license and indicate if changes were made.

The images or other third party material in this chapter are included in the chapter's Creative Commons license, unless indicated otherwise in a credit line to the material. If material is not included in the chapter's Creative Commons license and your intended use is not permitted by statutory regulation or exceeds the permitted use, you will need to obtain permission directly from the copyright holder. 